\title{
Influence of Structural Age Shifts of Population on Sectoral Structure of Employment
}

\author{
LIUBOV VODIANKA*1, ANDRII ANTOKHOV ${ }^{2}$, NATALIIA PODLUZHNA ${ }^{3}$, IRYNA ANTOKHOVA ${ }^{4}$, \\ VIKTOR SAICHUK ${ }^{5}$, ZORIANA KOBELIA ${ }^{6}$ \\ ${ }^{1,6}$ Department of Business and Human Resource Management, YURIY FEDKOVYCH CHERNIVTSI NATIONAL \\ UNIVERSITY, UKRAINE. *E-mail: I.vodjanka@chnu.edu.ua \\ ${ }^{2}$ Department of Economic Theory, Management and Business Administration, YURIY FEDKOVYCH CHERNIV-TSI \\ NATIONAL UNIVERSITY, UKRAINE. \\ ${ }^{3}$ Department of Economics, Accounting and Taxation, DONETSK NATIONAL TECHNICAL UNIVERSITY, UKRAINE. \\ ${ }^{4}$ Department of Business and Human Resource Management, YURIY FEDKOVYCH CHERNIVTSI NATIONAL UNI- \\ VERSITY, UKRAINE. \\ ${ }^{5}$ Department of International Tourism and Country Studies, NATIONAL AVIATION UNIVERSITY, UKRAINE.
}

\begin{abstract}
This article examines the correlation between the increase in age groups of population and branch structure of employment in the Ukrainian economy. Today, the study of human capital's impact on economic processes is an essential economic science component. The application of quantitative methods in this relationship's study provides essential information about the nature of the interconnection of individual characteristics of human capital and critical socio-economic processes in the current domestic economic reality. Applying correlationregression analysis, modelling these interdependencies with multiple regression models, and estimating correlation and deterministic relationships, in particular, are essential means in the practical study of this macroeconomic resource impact. Economic and mathematical analysis of the interdependencies between employment in agricultural, industrial, and financial sectors and the growth of the Ukrainian population's age groups were carried out. Based on these data, conclusions were drawn about critical macroeconomic processes, which are quantitatively confirmed by the built models. The role of the age structure of the population in structural transformations of the Ukrainian economy was evaluated.
\end{abstract}

Keywords: Correlation-regression analysis; human capital; econometric model; economic and demographic processes.

Clasificación JEL: B22, B23, E24, J16 


\section{Introduction}

An essential component of national economy labor resource analyses is their characteristics research in dynamics and integral influence on employment branch structure. The determination of labor resource's influence on the growth of individual branches of the country's economy can determine the vector of strategic development on both local and macroeconomic levels. Considering the context of this economic determinant's development in advanced countries, the dynamics of individual age groups can determine the level of society's development, dynamics of its development in specific directions, improvement of the social responsibility sphere, and liberalization of separate social and economic relationships. Thus, this aspect can be a functioning mechanism both of separate markets and the institutional sphere, determining the change of institutional and neo-institutional factors of economic development.

\section{Literature review}

Investigations in labor resources analysis are quite relevant, both among Ukrainian economists and international experts in this field. In particular, Shpak N.O., Stanasiuk N.S., Hlushko O.V., Sroka W. (2019) created the method of assessing industrial potential's social and labor components in the context of corporate social responsibility. Prokopenko O.V., Domashenko M.D., \& Shkola V.Y. (2014) have defined management features of economic security in foreign economic activity of Ukrainian machine-building enterprises while social and economic issues are the basis of economic security.

The research in this area was related to the study of macroeconomic transformations of the economy's branch structure in the context of dynamic changes of Ukrainian labor resources indicators (Zayukov et al., 2020).

Bakhov I. \& Boichenko, E. (2019) established the problems of labor market formation in Ukraine's current realities in the period of labor market formation. Age changes are studied for different purposes, such as the formation of the system of strategic change management within an enterprise and analysis of the relationship between changes in the age structure of the employment and wages of individuals in minor occupational groups (Dźwigoł, 2019; Broniatowska et al., 2020).

The importance of knowledge transfer on the energy market was investigated as one of the most critical factors of labor resources development (Miśkiewicz, 2018). Kwilinski A., Dzwigol H., \& Dementyev V. (2020) suggested the model of entrepreneurship financial activity of the transnational company based on intelligent technology. Public-private partnerships are considered a useful tool in R\&D activity that helps to develop the human capital of a particular company and human capital of a country in general (Zakharkin et al., 2019). The subjects of their researches were related to human resource studies, taking into account their dynamics in urban economies, their development, and their impact on the economies of separate world regions, management of labor resources, their structure, and dynamic growth (Boon et al., 2018).

Human capital development on economic and social development has been revealed (Lonska \& Mietule, 2015). The scholars argue that there is a bidirectional link: one runs from human capital development to economic growth and overall human development, when human capital helps increase national income and social development; the other runs from economic growth to human capital development, as the resources from national income, are allocated to activities contributing to human capital development. The problem of modelling human capital dynamics considers three components of capital: educational, health, and cultural (spiritual) (Ketova et al., 2019).

To put into effect analysis of dynamic macroeconomic changes of Ukrainian labor resources age structure, having investigated their impact on population employment branch structure. To study and determine the real influence of those changes, it is worth realizing a correlation-regression analysis and build the models of separate branches' functioning, depending on the growth of population age groups during an extended time. To fulfill an objective analysis of every age group and formulate 
conclusions, representing the influence of labor resources dynamics on the economy's structural transformation.

\section{Theoretical Background Conclusions}

One of the most important factors of economic development is its labor resources. This particular economic element is determined by one factor and depends on the integral action of social, economic, political, technological, institutional, and neo-institutional factors (Inshakov \& Frolov, 2011). Besides, this macroeconomic resource's characteristics are determined by preliminary indicators, i.e., they are autoregressive.

The structure of both labors resources in the age aspect and branch structure of employment has undergone significant changes for 10-20 years due to the factors described above. During such a period, the Ukrainian economy is characterized by macroeconomic instability, the impact of negative cyclic deformations on demographic processes, socio-economic, technological, and institutional changes.

It is worth noting that under the influence of these factors, the branch structure of national production was forced to respond both to national and international labor market tendencies, which often dictate the conditions for both branch structural changes in employment in the economy and positive or negative socio-demographic processes. It should be noted that the growth of this factor of economy in the branch context depends on previous indices of population age structure since the growth of separate age groups at one time can have a multiplicative effect on the dynamics of changes in a particular sector of the economy. Consideration of these issues should be related to the employment dynamics analysis of national economy separate sectors and the growth of age groups.

\section{Research Results}

With the State Statistics Service's online resource information, the data for 2000-2018 on employment in specific economic sectors have been consolidated. Also, information about the dynamics of industry structure indicators was obtained. Table 1 demonstrates it.

As shown, every year, the age structure of the population changes. The most considerable reductions were reported by the largest population groups aged 0-14 and 17-59. It should be noted that a significant decrease of population occurred under the influence of occupation of the south-eastern regions of Ukraine in 2014, namely the Crimean Peninsula and a large part of Donetsk and Luhansk regions, where considerable domestic labor resources were concentrated. Over the last three years, mixed tendencies have been observed in groups, with an increase, mainly due to the sufficiently large scale of the labor migration phenomenon, the 17-59 age group, a negative average increase of 320 thousand persons per year. It indicates that every year a significant part of Ukraine's primary human resources goes abroad to provide the families with financial resources, thereby generating GDP in other countries. Besides, over the last three years, we can observe the settling of negative trends in the $0-14$ age group's growth.

In particular, during 2016-2017, there was a positive increase of 45,1 and 41,2 thousand persons. To determine a specific impact of these factors, we need to apply a correlation-regression analysis, which will be realized through constructing multiple regressions of employment connection in a particular industry, depending on age group growth. The general form of this type of regressions is as follows (Ivashchuk, 2008; Runkler, 2012):

$$
y_{i}=a+b_{1} x_{1 i}+b_{2} x_{2 i}+\cdots+b_{m} x_{m i}+\delta_{i}, \quad i=\overline{1, n}
$$

where $a, b_{1}, b_{2}, \ldots, b_{m}$ - parameter estimates $\alpha, \beta_{1}, \beta_{2}, \ldots, \beta_{m}$, a $\delta_{i}$, - estimation of theoretical deviation $\varepsilon_{i},(i=\overline{1, n})$. 
Liubov Vodianka, Andrii Antokhov, Nataliia Podluzhna, Iryna Antokhova, Viktor Saichuk, Zoriana Kobelia

Table 1. Chain dynamics of population age group growth in Ukraine during 2000-2018

\begin{tabular}{|l|c|c|c|c|c|c|}
\hline & $\begin{array}{c}\text { Total population } \\
\text { growth }\end{array}$ & $\begin{array}{c}\text { Ages 0-14 in- } \\
\text { crease }\end{array}$ & $\begin{array}{c}\text { Ages 14-17 in- } \\
\text { crease }\end{array}$ & $\begin{array}{c}\text { Ages 17-59 in- } \\
\text { crease }\end{array}$ & $\begin{array}{c}\text { Ages 59-64 in- } \\
\text { crease }\end{array}$ & $\begin{array}{c}\text { Ages } 65 \text { and up } \\
\text { increase }\end{array}$ \\
\hline $\mathbf{2 0 0 0}$ & $-429,80$ & $-425,00$ & 71,30 & $-146,60$ & 224,50 & $-82,70$ \\
\hline $\mathbf{2 0 0 1}$ & $-451,40$ & $-407,70$ & 32,40 & $-94,00$ & 25,20 & 25,10 \\
\hline $\mathbf{2 0 0 2}$ & $-422,70$ & $-423,40$ & $-10,30$ & $-104,80$ & $-29,10$ & 134,60 \\
\hline $\mathbf{2 0 0 3}$ & $-417,80$ & $-380,40$ & $-48,00$ & 159,90 & $-412,10$ & 214,80 \\
\hline $\mathbf{2 0 0 4}$ & $-381,00$ & $-323,20$ & $-52,10$ & 200,10 & $-433,80$ & 175,90 \\
\hline $\mathbf{2 0 0 5}$ & $-341,60$ & $-256,50$ & $-117,60$ & 141,70 & $-364,70$ & 137,90 \\
\hline $\mathbf{2 0 0 6}$ & $-351,30$ & $-225,10$ & $-102,10$ & 155,80 & $-341,90$ & 59,90 \\
\hline $\mathbf{2 0 0 7}$ & $-283,50$ & $-158,30$ & $-107,60$ & $-12,30$ & $-148,90$ & 36,00 \\
\hline $\mathbf{2 0 0 8}$ & $-273,40$ & $-105,30$ & $-105,10$ & $-61,30$ & $-10,40$ & $-96,40$ \\
\hline $\mathbf{2 0 0 9}$ & $-228,90$ & $-24,90$ & $-114,50$ & $-152,50$ & 137,80 & $-189,30$ \\
\hline $\mathbf{2 0 1 0}$ & $-180,80$ & 7,40 & $-112,60$ & $-257,40$ & 217,80 & $-148,60$ \\
\hline $\mathbf{2 0 1 1}$ & $-184,40$ & 12,40 & $-90,20$ & $-238,50$ & 245,30 & $-203,60$ \\
\hline $\mathbf{2 0 1 2}$ & $-144,90$ & 35,50 & $-67,20$ & $-247,90$ & 104,20 & $-36,70$ \\
\hline $\mathbf{2 0 1 3}$ & $-80,60$ & 89,10 & $-70,30$ & $-219,30$ & 72,80 & $-23,20$ \\
\hline $\mathbf{2 0 1 4}$ & $-126,80$ & 90,10 & $-70,60$ & $-250,40$ & 10,00 & 23,50 \\
\hline $\mathbf{2 0 1 5}$ & $-2486,20$ & $-261,50$ & $-133,70$ & $-1759,20$ & $-212,50$ & $-253,00$ \\
\hline $\mathbf{2 0 1 6}$ & $-168,80$ & 45,10 & $-45,80$ & $-295,90$ & $-11,10$ & 93,10 \\
\hline $\mathbf{2 0 1 7}$ & $-176,00$ & 41,20 & $-39,60$ & $-335,40$ & 19,60 & 98,60 \\
\hline $\mathbf{2 0 1 8}$ & $-198,10$ & $-5,00$ & $-1,30$ & $-340,70$ & 47,80 & 99,80 \\
\hline $\mathbf{2 0 0 1 0}$ & -20 & & & & \\
\hline
\end{tabular}

Source: Formed based on the State Fiscal Service of Ukraine data (2000-2018).

The construction of multiple regression is based on the method of the least squares (MLS). This method is fundamental in economic and mathematical modeling and is widely used to model both micro and macroeconomic processes (Grygorkiv, 2009; Yin, 2018). The essence of this method lies in finding the coefficients-estimates of the influence of factors, provided that the squares of deviation of the dependent variables real statistical values and the values obtained from the modeled functional dependence of the dependent and explanatory variables are the least, that is, the solution of the problem like (Ivashchuk, 2008):

$$
F\left(a, b_{1}, b_{2}, \ldots, b_{m}\right)=\sum_{i=1}^{n}\left(y_{i}-\left(a-\sum_{j=1}^{m} b_{j} x_{i j}\right)\right)^{2} \rightarrow \min ,(i=\overline{1, n}, j=\overline{1, m})
$$

As the regression operates with several explanatory variables at once, establishing the estimates of the regression parameters will be reduced to finding the vector of estimates based on the OLS. Mathematically, this can be represented as follows:

$$
\bar{b}=\left(\tilde{X}^{T} \tilde{X}\right)^{-1} \tilde{X}^{T} \tilde{Y}
$$

where $\tilde{X}$ - matrix of factor variables, $\tilde{X}^{T}$ - transposed matrix of factor variables, $\tilde{Y}$ - matrix of dependent variables. The study has also evaluated the regression parameters and their adequacy based on comparison with the Student and Fisher's criterion and established multiple correlation and determination coefficients.

Therefore, table 2 shows the results of constructing a multiple regression of the employment in agriculture dependence on the growth of population age groups of Ukraine. Analyzing the data in table 2, it should be noted that the relationship between the employment in agriculture and population age group growth is quite close. The multiple correlation coefficient is 0.9479 , which in turn indicates a close relationship. This is also evidenced by an adjusted multiple determination coefficient of 0.8594 . It should be noted that the employment in agriculture is most influenced by the increase 
in the 0-14 age group, which shows the inverse relationship, and the increase in the 17-59 group, which has a direct connection.

Table 2. A regression model of employment in agriculture according to the increase in age groups

\begin{tabular}{|c|c|c|c|c|c|c|}
\hline Name & a & $\mathrm{b}_{1}$ & $b_{2}$ & $b_{3}$ & $\mathrm{~b}_{4}$ & $b_{5}$ \\
\hline $\begin{array}{l}\text { The overall appearance of the model without } \\
\text { considering the significance of the parameter } \\
\text { estimates }\end{array}$ & 3392,06 & $-2,03$ & 1,036 & 0,6133 & 0,04 & $-0,601$ \\
\hline $\begin{array}{l}\text { The significance of parameter estimates } \\
\text { (t-Student's criterion=2,093) }\end{array}$ & + & + & - & + & - & - \\
\hline $\begin{array}{l}\text { Model appearance after considering the signifi- } \\
\text { cance of the estimates }\end{array}$ & \multicolumn{6}{|c|}{$y_{i}=3392,06-2,03 x_{1 i}+0,6133 x_{3 i}$} \\
\hline Multiple correlation coefficient & \multicolumn{6}{|c|}{0,9479} \\
\hline Adjusted multiple coefficients of determination & \multicolumn{6}{|c|}{0,8594} \\
\hline
\end{tabular}

Source: Calculated by authors

It proves that with the renewal of labor resources and the emergence of young people, agriculture's popularity is decreasing. This phenomenon can be explained by the fact that in order to maintain this age group, older people have to move to other economic sectors that are more profitable.

The industry of Ukraine and its relationship with population age group growth is one more sphere. Table 3 presents data on the correlation-regression analysis of such interdependencies.

Table 3. A regression model of employment in the industry according to population growth

\begin{tabular}{|c|c|c|c|c|c|c|}
\hline Name & a & $\mathrm{b}_{1}$ & $\mathrm{~b}_{2}$ & $b_{3}$ & $\mathrm{~b}_{4}$ & $b_{5}$ \\
\hline $\begin{array}{l}\text { The overall appearance of the model without } \\
\text { considering the significance of the parameter } \\
\text { estimates }\end{array}$ & 3215,86 & $-3,26$ & $-1,99$ & 1,234 & 0,4 & $-1,89$ \\
\hline $\begin{array}{l}\text { The significance of parameter estimates } \\
\text { (t-Student's criterion }=2,093 \text { ) }\end{array}$ & + & + & - & + & - & + \\
\hline $\begin{array}{l}\text { Model, after considering the significance of } \\
\text { the estimates. }\end{array}$ & \multicolumn{6}{|c|}{$y_{i}=3215,86-3,26 x_{1 i}+1,234 x_{3 i}-1,89 x_{5 i}$} \\
\hline Multiple correlation coefficient & \multicolumn{6}{|c|}{0,9792} \\
\hline $\begin{array}{c}\text { Adjusted multiple coefficients of determina- } \\
\text { tion }\end{array}$ & \multicolumn{6}{|c|}{0,943} \\
\hline
\end{tabular}

Source: Calculated by authors

The interdependence of those employed in the industry on the growth of age groups is also quite large. Multiple regression correlation is 0.9992 , indicating a significant-close linear relationship and an adjusted multiple determination coefficient of 0.943 , indicating a significant measure of sample response to the determinant change. The following regression features of the model are worth noting. After the procedure for estimating the significance of regression parameter estimates, only the estimates of the impact of the growth among the 0-14, 17-59, and 65 and older age groups of the population remained. Moreover, it should be noted that the first and third groups' connection is inverted and only in the second group is direct. This is because the second and third age groups of the population are determinative in this area and characterize the flow of labor resources into this industry. 
On the other hand, one should not forget about the growth of the first age group, which has an inverse effect on this employment sector. This group's growth is vital for understanding the impact of socio-demographic phenomena, such as labor migration. Accordingly, the increase in the number of children and adolescents causes many workers to leave their jobs and migrate abroad.

Equally important is finding a similar correlation in the financial sector, an essential component of the national economy. Understanding the impact of the interdependence between employment in this area and the growth of age groups makes it possible to look at this phenomenon from an entirely different perspective. Table 4 shows the data on the correlation-regression analysis of the impact of population growth on employment in the financial sphere (Perevozova et al., 2019).

Table 4. A regression model of employment in financial activity according to population growth

\begin{tabular}{|c|c|c|c|c|c|c|}
\hline Name & a & $b_{1}$ & $b_{2}$ & $b_{3}$ & $\mathrm{~b}_{4}$ & $b_{5}$ \\
\hline $\begin{array}{c}\text { The overall appearance of the model without } \\
\text { considering the significance of the parameter } \\
\text { estimates }\end{array}$ & 254,57 & 0,106 & $-0,705$ & 0,084 & 0,0125 & $-0,29$ \\
\hline $\begin{array}{l}\text { The significance of parameter estimates } \\
\text { (t-Student's criterion }=2,093 \text { ) }\end{array}$ & + & - & + & + & - & + \\
\hline $\begin{array}{c}\text { Model after considering the significance of } \\
\text { the estimates }\end{array}$ & \multicolumn{6}{|c|}{$y_{i}=254,57-0,705 x_{2 i}+0,084 x_{3 i}-0,29 x_{5 i}$} \\
\hline Multiple correlation coefficient & \multicolumn{6}{|c|}{0,9507} \\
\hline $\begin{array}{c}\text { Adjusted multiple coefficients of determina- } \\
\text { tion }\end{array}$ & \multicolumn{6}{|c|}{0,867} \\
\hline
\end{tabular}

Source: Calculated by authors

Analysing the data in Table 4, it should be noted that the employment of such age groups as the population aged 14-17, 17-59, and 65 and over have a significant impact on financial sphere employment. The second age group's correlation is direct, and that of the second and third is inverse. The costs of the population age group 14-17 maintaining are slightly lower than those for representatives of the age group $0-14$, which contributes to the reduction of the population's financial activity and, accordingly, the volume of financial market entities activity. A similar effect can be observed in the population age group 65 years and over. The increase of its representatives contributes to the decrease in financial activity in the economy.

In contrast, the increase of labor resources basis - i.e., the number of people aged 17-59 contributes to the revitalization of economic activity and the financial sector. A close correlation of 0.9507 and a high level of age growth determination after adjustment of 0.867 should also be estimated. Population growth is a crucial component of the impact of human capital on the domestic economy. Quantitative studies of the determination of this factor on the branch structure of employment are a promising research area that may exist in the field of economic science and interdisciplinary research that underlies the argumentation of institutional neo-institutionalism.

\section{Conclusions}

Based on the analysis of the impact of structural age changes of the population on the sectoral structure of employment, we conclude the following:

1. Multiple regression of the dependence of employment in the field of agriculture, industry, and financial activities on the growth of age groups of Ukraine's population is constructed.

2. It was found that the transformation of the employment structure is, first of all, by changes in the structure of the region's economy. It is worth noting that the sphere of employment in agriculture is most affected by the growth of the age group 0-14 years, which shows an inverse relationship, and the growth of the group 17-59 years, which has a direct relationship. It indicates that with the renewal 
of labor resources and the emergence of young people, agriculture's popularity is declining. This phenomenon can be explained by the fact that in order to maintain this age group, older people have to move to other, more profitable areas of the economy.

3. Multiple regression of the dependence of employment in the industry on the growth of age groups in Ukraine indicates a significant impact of the group 0-14 years. This group's growth is vital for understanding the impact of socio-demographic phenomena, such as labor migration. Accordingly, the increase in the number of children and adolescents encourages many employees to resign from their jobs and carry out labor migration abroad.

4. Analyzing the data on the impact of the growth of age groups on employment in financial activities, it can be noted that the growth of such age groups as the population aged 14-17, 17-59, and 65 and older.

5. Structural changes in employment are currently destructive. A significant share (36.2\%) of workers are employed in industry and agriculture, which indicates a significant lag of the domestic, regional structure of employment from European standards. Employment growth is due to increased workers in services, education, science, innovation.

6. It should be noted that age groups' growth is a crucial component of the impact of human capital on the domestic economy. Quantitative research on the determination of this factor on the sectoral structure of employment is a promising research area that can exist not only in economics but also in interdisciplinary research that is the basis for the argument of institutionalism and neo-institutionalism.

\section{References}

1. Bakhov, I., \& Boichenko, E. (2019). Labor market management: Analysis, control and optimization of employment. Journal of Advanced Research in Dynamical and Control Systems, 11(10), pp. 587-594.

2. Boon, C., Eckardt, R., Lepak, D.P., \& Boselie, P. (2018). Integrating strategic human capital and strategic human resource management. International Journal of Human Resource Management, 29(1), pp. 34-67.

3. Broniatowska, P., Majchrowska, A., \& Nasinski, M. (2020). Age structure of employment and wages. An analysis across occupational groups. Central European Journal of Economic Modelling and Econometrics, 3, pp. 1-24.

4. Dźwigoł, H., Shcherbak, S., Semikina, M., Vinichenko, O., \& Vasiuta, V. (2019). Formation of Strategic Change Management System at an Enterprise. Academy of Strategic Management Journal, 18(SI1), 1-8. Retrieved from https://www.abacademies.org/articles/Formation-ofstrategic-change-management-system-at-enterprise-1939-6104-18-SI-1-454.pdf

5. Grygorkiv, V. (2009). Econometrics: Linear models of pairwise and multiple regression: Textbook. Chernivtsi: CHNU, 224p.

6. Inshakov, O., \& Frolov, D. (2011). Institution - the key to understanding economic institutions. Economy theory. №1. p.52-62.

7. Ivashchuk, O. (2008). Economic and mathematical modeling: Textbook. Ternopil: TNEU "Economic thought», 704p.

8. Ketova, K.V., Romanovsky, Yu.M., \& Rusyak, I.G. (2019). Mathematical modeling of the human capital dynamics. Computer Research and Modeling, 11(2), pp. 329-342.

9. Kwilinski, A., Dzwigol, H., \& Dementyev, V. (2020). Model of Entrepreneurship Financial Activity of the Transnational Company Based on Intellectual Technology. International Journal of Entrepreneurship, 24 (Special Issue: Entrepreneurship, Innovation Management and Sustainability), 1-5. Retrieved from https://www.abacademies.org/articles/Model-ofEntrepreneurship-Financial-Activity-of-the-Transnational-Company-Based-on-IntellectualTechnology.pdf 
10. Lonska, J., \& Mietule, I. (2015). The impact of human capital development on the economic and social development of a country: Empirical study. Vide. Tehnologija. Resursi - Environment, Technology, Resources, 2, pp. 174-180.

11. Miśkiewicz, R. (2018). The importance of knowledge transfer on the energy market. Polityka Energetyczna, 21(2), 49-62. http://dx.doi.org/10.24425\%2F122774

12. Occupied economic population by type of economic activity. Statistical information. State Service Statistics: Official Web Resource. Retrieved from http://www.ukrstat.gov.ua .

13. Prokopenko, O.V., Domashenko, M.D., \& Shkola, V.Y. (2014). Management features of economic security in foreign economic activity of ukrainian machine-building enterprises. Actual Problems of Economics, 160(1), pp. 188-194.

14. Runkler, T. (2012). Data Analytics: Models and Algorithms for Intelligent Data Analysis. Siemens AG, München und Technische Universität München, pp. 1-137.

15. Shpak, N.O., Stanasiuk, N.S., Hlushko, O.V., \& Sroka, W. (2018). Assessment of the social and labor components of industrial potential in the context of corporate social responsibility. Polish Journal of Management Studies, Volume 17, Issue 1, Pages 209-220. DOI: 10.17512/pjms.2018.17.1.17.

16. Sinay, L., Carter, R.W., \& de Sinay, M.C.F. (2020). In the race for knowledge, is human capital the most essential element? Humanities and Social Sciences Communications, 7(1).

17. Yin, X. (2018). Construction of management system for coordination degree of regional economic development based on the fusion of spatial econometric model. Proceedings - 10th International Conference on Measuring Technology and Mechatronics Automation, ICMTMA 2018, pp. 489492, Code 135881.

18. Zakharkin, O., Basantsov, I., Shcherbachenko, V., \& Zakharkina, L. (2019). Public-private partnership as an effective tool in R\&D activity. 2019. Proceedings of the 33rd International Business Information Management Association Conference, IBIMA 2019: Education Excellence and Innovation Management through Vision 2020. pp.6674-6678.

19. Zayukov, I., Overchuk, V., Burdiak, V., Velykyi, Y., Butyrska, I., \& Butenko, V. (2020). Statistical data analysis of socio-economic and demographic losses of labor resources in Ukraine. Montenegrin Journal of Economics,16(2), pp. 179-192. 